\title{
Dental Health Service Seeking Behavior on Indonesian Social Insurance Administration Organization
}

\author{
Hermien Nugraheni*, Tri Wiyatini, Sadimin \\ Poltekkes Kemenkes Semarang, Indonesia
}

*Corresponding Author: Hermien Nugraheni, Politeknik Kesehatan, Kemenkes Semarang, Jl. Tirto

Agung Pedalangan, Banyumanik, Indonesia, Email: hermienprajoga@gmail.com

\begin{abstract}
Background: Health insurance for Indonesian people is run by a government agency for social insurance administration organization known as Badan Penyelenggara Jaminan Sosial (BPJS). However, still, some people are reluctant to use this agency's service for dental care.
\end{abstract}

The Objective: The purpose of this study was to analyze the factors affecting dental health care seeking behavior of health care facilities at the Indonesian Social Insurance Administration Organization in Semarang, Central Java.

Methods: This research is an explanatory research with the cross-sectional design. Data have been obtained in this study then performed statistical tests to test bivariate analysis, conducted by analysis of relationships using the t-test to assess whether the mean and the diversity of the two groups (those using the service and not) were statistically different from each other.

Result: The results showed that accessibility of patients concerning distance affect the use of dental health service covered by the insurance agency to overcome the problem of oral health. A convenience to get followup services and the compatibility between the functions obtained in the hope affect the use of dental health service with the insurance agency to overcome the problem of oral health.

Conclusion: The most influential factor in the use of dental and oral health services at the health services insurance agency in Semarang to address oral health problems is accessibility regarding the distance.

Keywords: Dental health, health-seeking behavior, social insurance agency

\section{INTRODUCTION}

Dental and oral diseases are the first on the list of top ten diseases most often complained of Indonesian society. Indonesia public perceptions and behaviors towards oral health are less compared to other sectors. This condition is evident from the still significant number of dental caries and oral disease in Indonesia which is likely to increase (Depkes, 2009).

Every healthcare effort requires cooperation from the health service users that should know how and why someone behaves in specific ways and how they might be attached to such behavior. In Indonesia, essential health services intended to allow the entire community obtains adequate health care. Provision of the health clinic with dental care is one of the efforts made to meet the dental care needs. The purpose of this study was to analyze the factors that affect dental health-seeking behavior at healthcare facilities with the health services insurance agency managed by an Indonesian social insurance administration organization or known as BPJS in Semarang. BPJS stands for Badan Penyelenggara Jaminan Sosial or Social Insurance Administration Organization. All Indonesian citizens must become the health insurance managed by this agency.

\section{MATerials AND MethodS}

This research is an explanatory research with a cross-sectional design. In this study, the univariate analysis was used to determine the proportion of each study variable. The data have been obtained in this study then performed statistical tests to test bivariate investigation, conducted by analysis of relationships using the t-test to assess whether the mean and the diversity of the two groups were statistically different from each other. The sample was respondents who become the object of this study 
are a non-member of BPJS was $6(4.6 \%)$, and the member was 124 people $(95.4 \%)$. The accessibility of respondents was measured with of residence's respondent distance to dental healthcare facilities and ability to pay the service fee. Characteristic needs of respondents to dental health services insurance agency expressed by the perception of compatibility between the services obtained with hope, comfort, friendliness officer (dentists and dental nurses), length of time waiting for assistance and ease in getting follow-up services.

\section{RESULT}

Respondents who become the object of this study $(100 \%)$ feel confident that by searching for dental and oral health care in a dental health services insurance agency, it will address dental health problems. Likewise, it turns out that $100 \%$ of respondents felt confident that by following the procedure of oral health services provided in healthcare insurance agency will overcome the problem of oral health.

Accessibility of respondents to dental health services insurance agency includes convenience regarding residence's respondent within dental healthcare facilities or ability to pay the service fee. In this study, 118 respondents (90.8\%) stated that they had no difficulty regarding the distance to access dental health services insurance agency, while 12 others $(9.2 \%)$ had trouble concerning the distance to locate dental health services insurance agency. While the views of accessibility costs or ability to pay the respondent in obtaining dental health services insurance agency, $129(99.2 \%)$ was willing to pay and one person $(0.8 \%)$ said it was not able to pay.

Characteristic needs of respondents to dental health services insurance agency is the need respondents to seek treatment expressed by the perception of compatibility between the services obtained with hope, comfort, friendliness officer (dentists and dental nurses), long time waiting for assistance and ease in getting follow-up services. This study showed that: $90 \%$ of respondents feel comfortable with the dental health services insurance agency, 100\% of respondents said that doctors and nurses are friendly, be kind and fun, and can communicate well. Furthermore, $90 \%$ of respondents stated that the waiting time to get the service quite reasonable, $91.5 \%$ of respondents said that if the necessary follow-up, there was no trouble to get the service, as well as $100 \%$ of respondents, stated that the service provided was as expected.
The analysis of relationships using the t-test between accessibility of respondents to using the health services insurance agency found that the value of $\mathrm{p}$ (p-value $)=0.000$, which means that there is a relationship regarding the distance to dental health care facilities with using the health services insurance agency.

The analysis of relationships using t-test on the perception of respondents about the ease of getting follow-up services found that the value of $p(p$-value $)=0.005$. This figure means that there is a connection between the perception of respondents about the ease of getting follow-up services on dental health services with the insurance agency and using of dental health services with the insurance agency.

Similarly, the analysis of relationships using ttest on the perception of respondents about the suitability of the services found that the value of $\mathrm{p}(\mathrm{p}$-value $)=0.002$, which means that there is a connection between the perception of respondents about the suitability of the services available to

Of the three variables associated with the use of dental health services with the insurance agency, it turned out to be the most closely related is variable affordability regarding range of dental health services with insurance agency against the use of dental health services with insurance agency with $p=0.009$. The regression quotient $=49.109$ meaning that the participants were far away from the location of the dental health services will not use dental health services with insurance agency 49.109 times higher compared to participants living near the site of the dental health services of the insurance agency.

\section{DISCUSSION}

There is a relationship between accessibility respondents concerning distance on dental health services with the use of dental health services covered by the insurance agency. The development of the urban community is now so right, where the availability of means of transport is quite easy to get, either public transportation or bike rental. Also, the condition of the road connecting to the service is excellent, and the cost of transportation are easily accessible as well as the smoothness of city transportation available to make people who have a home away from dental health services do not feel it as an obstacle to go. Difficulty in accessing health care can be resolved by the availability of facilities and infrastructure supporting the transport of the populated areas 
that are far away from the location of dental health services. This could be linked to internal factors from the family or the patient. The level or degree of disease are increasingly more severe; then the individual will be needed healing thus will be more need for health services, as well as the needs of healthcare if the higher the need for a service then the higher the desire to utilize health services (Manurung, 2008).

There is a connection between the perceptions of respondents about the ease of getting the follow-1up services with the use of dental health services covered by the insurance agency. Hasbi (2012) suggests that the perception of an abstract nature is factors that affect the satisfaction of a certain form and not something concrete or actual. Perception itself has an aspect that plays the most psychological of a person. Their attitude establishes good communication and also supports the physical environment situation around the patient or society is an assessment aspect affecting the community itself.

Communication with patients and information about a service process that is being provided will lead to a positive perception and support to be able to receive a given action. Fast service response and supported the friendly attitude and sincerity in responding to the problems faced and the clarity and speed in providing follow-up services are supporting and helping to determine the success of the health service and also affect the patient's recovery.

Perception is a process in a person in understanding the circumstances or situations in their environment that involves organizing and interpretation as a stimulus in a psychological experience. Impressions are formed in a process with sufficient time to be able to generate a response. Their perception can help a person in selecting and interpreting a felt or seen to form a full and meaningful as what appears.

Improved quality of service is related to the speed of response and reliability of health workers, improving health facilities and the availability of the drug should be improved. This way, the public perception of the National Health Insurance Program also getting higher and eventually utilization of dental health service with insurance agency is getting better in the sense that the service is dental health service covered by the insurance agency be chosen by the public in understanding oral health. (Purwatiningsih,2008).
There is a relationship between the respondent's perception about the appropriateness of services obtained by the expected on dental health service with insurance agency with the use of dental health service with the insurance agency. Their choice to utilize or not utilize health services by health care facilities is a real form of relating to patients' perceptions. This is stated in the study that indicates that the understanding of health workers and knowledge of the National Health Insurance Program less will encourage underutilization of health care facilities.

A statement choose or not choose, utilize or not utilize healthcare facilities associated with an assessment like it or not to the service with the given. This attitude is also a result of the evaluative aspects of the collection of information and to form concrete produced in the form of action. A person's perspective is strongly influenced by their patient assessment criteria are processed in the understanding, and the requirements are formed through a process of social interaction with other people (Suprihanto, 2003).

The public perception of excellent service from the clinic gives the impression of depth and motivation to take advantage of the health services provided. When people find out that the provision of services following the expected then the trust and satisfaction will increase (Notoatmodjo, 2010).

The most dominant factor about the use of dental health service with insurance agency is accessibility regarding the distance of the respondent with facility layout dental health service with insurance agency against the use of dental health service with the insurance agency. Implementation services from health insurance agency good health-related quality of services provided. If the quality of service is right, then the service recipient patient will be satisfied and encourage interest to take advantage of the health service. Quality of service can be determined by human resources which is the amount and reliability of health workers, adequate supporting facilities, the collateral health services and the availability and drug completeness at the point of healthcare (Alamsyah, 2011).

\section{CONCLUSION}

Accessibility of patients regarding distance affects the use of dental health service covered by the insurance agency to overcome the problem of oral health. A convenience to get 
follow-up services and the compatibility between the functions obtained in the hope affect the use of dental health service with the insurance agency to overcome the problem of oral health. The factors that most influence on the use of dental health service with insurance agency are accessibility concerning distance.

\section{REFERENCES}

[1] Alamsyah, D. 2011. Manajemen Pelayanan Kesehatan. Yogyakarta: Nuha Medika.

[2] Depkes RI, 2009. Pedoman Survey Dasar Kesehatan Gigi dan Mulut di Indonesia, Direktorat Jenderal Pelayanan Medik, Jakarta.

[3] Hasbi, H. 2012. Analisis Hubungan Persepsi Pasien tentang Mutu Pelayanan dengan Pemanfaatan Ulang Pelayanan Rawat Jalan
Puskesmas Poncol Kota Semarang.Tesis. http://www.eprints.undip.ac.id/37026/.

[4] Manurung, AM. 2008. Hubungan Perceived dan Evaluated Need Perawatan Karies Gigi dengan Pemanfaatan Pelayanan Kesehatan Gigi Pada Masyarakat di Kota Pematang Siantar. Tesis. http://repository.usu.ac.id/bitstream/12 3456789/6735/3/08E00056.pdf.txt.

[5] Notoatmodjo, Soekidjo. 2010. Ilmu Perilaku Kesehatan. Jakarta. Rineka Cipta.

[6] Purwatiningsih, R. 2008. Persepsi Masyarakat tentang Peranan Puskesmas. Skripsi. Online. (http://eprints.uns.ac.id/8611/1/914803 08200909381.pdf)

[7] Suprihanto, J., TH.A.M. Harsiwi, P. Hadi. 2003. Perilaku Organisasi. Yogyakarta: Penerbit Sekolah Tinggi Ilmu Ekonomi Yayasan Keluarga Pahlawan Negara.

Citation: Hermien Nugraheni, Tri Wiyatini, Sadimin. Dental Health Service Seeking Behavior on Indonesian Social Insurance Administration Organization. ARC Journal of Public Health and Community Medicine.2017; 2(4):33-36: dx.doi.org/10.20431/2456-0596.0204006.

Copyright: (c) 2017 Authors. This is an open-access article distributed under the terms of the Creative Commons Attribution License, which permits unrestricted use, distribution, and reproduction in any medium, provided the original author and source are credited. 